\title{
Karakteristik performance individu muda di Desa Ngablak dan hubungannya dengan penyalahgunaan NAPZA
}

\author{
Suhartini, ${ }^{1, *}$ Neni Trilusiana Rahmawati, ${ }^{2}$ Yudha Nurhantari, ${ }^{1}$ Hendro Widagdo, ${ }^{1}$ \\ Idha Arfianti Wira Agni ${ }^{1}$ Martiana Suciningtyas, ${ }^{1}$ Wikan Basworo ${ }^{1}$ \\ ${ }^{1}$ Departemen Ilmu Kedokteran Forensik dan Medikolegal, '2Laboratorium Bioantropologi dan \\ Paleoantropologi, Fakultas Kedokteran, Kesehatan Masyarakat, dan Keperawatan, Universitas Gadjah \\ Mada, Yogyakarta, Indonesia
}

\section{Submitted: 5 September 2018 Revised: 9 November 2018 Accepted: 24 November 2018}

\begin{abstract}
ABSTRAK Alkohol, narkotika, psikotropika, dan zat adiktif lainnya (NAPZA) merupakan substansi yang sering disalahgunakan. Mayoritas pengguna alkohol dan NAPZA adalah remaja dengan rentang usia 13 - 17 tahun di mana penyalahgunan ini dapat berpengaruh terhadap komposisi tubuh. Mempertimbangkan peran generasi muda sebagai penerus bangsa, banyak hal yang dapat dilakukan sebagai upaya pengentasan perilaku negatif ini. Salah satunya adalah melalui pengalihan kebiasaan penyalahgunaan alkohol dan NAPZA ke kegiatan positif seperti olahraga. Untuk mewujudkan hal ini, perlu dilakukan identifikasi pengembangan bakat olahraga sesuai dengan karakteristik performance yang dimiliki. Tujuan penelitian ini untuk mengetahui karakteristik performance generasi muda di Desa Ngablak dan hubungannya dengan penyalahgunaan NAPZA. Sebanyak 50 orang anggota karang taruna remaja di Desa Ngablak, Kecamatan Ngablak, Kabupaten Magelang diperiksa secara antropometrik, fisik (nadi, laju respirasi, tekanan darah, suhu), dan somatotipik (perawakan). Identifikasi generasi muda yang terlibat penyalahgunaan alkohol dilakukan menggunakan kuesioner. Hasil ditampilkan secara deskriptif. Dilakukan uji komparatif (uji t atau Mann Whitney) untuk mengetahui hubungan konsumsi alkohol dengan karakteristik performance. Usia subjek berkisar 9 - 19 tahun dengan 50\% laki-laki ( 25 orang). Sebanyak 13 laki-laki dan 2 perempuan mengonsumsi alkohol. Hasil pemeriksaan fisik menunjukkan bahwa seluruh subjek dalam rentang normal. Rerata usia, tinggi badan, dan berat badan subjek laki-laki yang mengonsumsi alkohol lebih tinggi daripada yang tidak $(p<0,05)$. Tidak ada perbedaan somatotipe antara remaja yang mengonsumsi alkohol dan yang tidak. Tipe tubuh subjek laki-laki berdasarkan pengukuran adalah tipe ideal, sedangkan pada remaja perempuan adalah tipe tubuh endo-mesomorfik. Kecenderungan penyalahgunaan alkohol tidak menyebabkan terjadinya perbedaan tipe badan pada remaja, baik pada laki-laki maupun perempuan.
\end{abstract}

KATA KUNCI somatotipe; ideal; endo-mesomorfik; NAPZA; olahraga

ABSTRACT Alcohol, narcotics, psychotropic substances and other addictive substances are substances that are often misused. The majority of drug users are adolescents with age ranging from $13-17$ years old at which abuse can affect body composition. Considering the role of the younger generation as the nation's successors, it sparks the urgency to alleviate this negative behavior. One of the measures that can be done is by shifting the negative activities to positive ones such as sports. In order to do this, it is necessary to identify the performance characteristics of the youths to maximize their potential. This study aimed to find out the performance characteristics of the younger generation in Ngablak Village and their association with drug abuse. A total of 50 youth members in Ngablak Village, Ngablak Subdistrict, Magelang Regency

\footnotetext{
*Corresponding author: Suhartini

Departemen IImu Kedokteran Forensik dan Medikolegal, Fakultas Kedokteran, Kesehatan Masyarakat, dan Keperawatan, Universitas Gadjah Mada, JI. Farmako, Sekip Utara, Yogyakarta 55281, Indonesia

E-mail: suhartini@ugm.ac.id
} 
were examined for anthropometry, physical (pulse, respiration rate, blood pressure, temperature), and somatotype associated with performance. Identification of subjects involved in alcohol and drug abuse was carried out using a questionnaire. The results were displayed descriptively. Statistical analyses (t-test or Mann Whitney $U$ test) were used to compare performance characteristics between groups. Age of subjects ranged from 9 - 19 years and 50\% were male. A total of 13 boys and 2 girls consumed alcohol. The results of physical examination showed the normal range in all subjetcs. The average age, height, and weight of male subjects who comsumed alcohol were higher than those who did not $(p<0,05)$. There was no difference in somatotype between adolescents who consumed alcohol and those who did not. The body type of male subjects based on measurements was the ideal type, whereas the female subjects had endomesomorphic body type. The tendency of consuming alcohol does not cause differences in body type in adolescents, both in male and female.

KEYWORDS somatotype; ideal; endo-mesomorphic; NAPZA; sports

\section{Pendahuluan}

Bangsa yang besar selalu memperhatikan generasi mudanya karena masa depan suatu bangsa tergantung pada kualitas mereka. Salah satu permasalahan pada generasi muda yang tidak hanya dihadapi bangsa Indonesia adalah penyalahgunaan alkohol, narkotika, psikotropika dan zat adiktif lainnya (NAPZA). Menurut World Health Organization (WHO), ${ }^{1}$ sebanyak 33,2\% remaja berusia 15 - 19 tahun yang mengonsumsi alkohol di Indonesia adalah peminum berat. Hasil survei riset kesehatan dasar (Riskesdas) menunjukkan sebanyak 4,6\% penduduk Indonesia mengonsumsi alkohol dan jumlah terbanyak peminum alkohol adalah usia produktif (15 - 34 tahun). ${ }^{2}$

Setelah masuk ke dalam tubuh, 90\% alkohol dimetabolisme di hati oleh enzim alkohol dehidrogenase menjadi asetaldehid yang toksik, selanjutnya oleh enzim aldehid dehydrogenase asetaldehid diubah menjadi asam asetat yang tidak toksik. ${ }^{3,4}$ Konsumsi alkohol yang berlebihan dapat memperberat kerja hati dan menyebabkan penyakit hati alkoholik. ${ }^{5} \mathrm{Di}$ samping itu, konsumsi alkohol dapat mempengaruhi antropometri dan komposisi tubuh karena berkorelasi negatif dengan akumulasi lemak tubuh terutama secara viseral. ${ }^{6}$

Selain mempengaruhi kesehatan, alkohol juga mempengaruhi kehidupan sosial dan merupakan salah satu faktor terjadinya kriminalitas. ${ }^{7}$ Alkohol mengganggu pemrosesan informasi yang dibutuhkan untuk menghambat impuls respons di otak. Semakin tinggi dosis alkohol, semakin tinggi kemungkinan seseorang yang mabuk untuk menyimpang dari perilaku normal. ${ }^{8}$ Konsumsi alkohol berlebihan dalam jangka lama membuat seseorang menjadi pribadi yang lebih permisif terhadap tindakan melanggar hukum sehingga berhubungan secara tidak langsung dengan kejahatan. ${ }^{9}$

Desa Ngablak, Kecamatan Ngablak, Kabupaten Magelang, Jawa Tengah, Indonesia, terletak di lereng Gunung Merbabu dengan ketinggian lebih dari $1500 \mathrm{~m}$ di atas permukaan laut. Kecamatan ini berbatasan dengan Kopeng, yakni salah satu objek wisata pegunungan di Kabupaten Semarang. ${ }^{10}$ Sebagian besar mata pencaharian penduduk Ngablak adalah petani atau buruh tani $(40,12 \%)$ dan sebagian kecil $(2,4 \%)$ berprofesi sebagai Pegawai Negeri Sipil (PNS), Tentara Nasional Indonesia (TNI), Kepolisian Republik Indonesia (Polri), atau pensiunan. ${ }^{11}$ Dari segi pendidikan, tingkat pendidikan tertinggi yang ditamatkan di wilayah Kecamatan Ngablak pada tahun 2010 paling banyak adalah tingkat sekolah dasar (SD), sedangkan yang paling sedikit adalah tingkat diploma dan universitas. ${ }^{12} \mathrm{Hal}$ ini menunjukkan tingkat pendidikan penduduk di Kecamatan Ngablak masih rendah. Pendidikan yang rendah dan penghasilan yang menjanjikan dari sektor ekonomi 
dan geografis (dekat tempat wisata) apabila tidak disikapi dengan benar, rentan terhadap pengaruh penyalahgunaan alkohol.

Masa remaja (generasi muda) adalah perubahan dari masa anak-anak menjadi dewasa. Remaja suka mencoba hal-hal baru termasuk meniru perilaku dari film-film yang bergaya hidup modern. Selain itu, mereka berada dalam fase pencarian jati diri dan senang berkelompok. Beberapa faktor linkungan yang memiliki korelasi positif dengan konsumsi alkohol pada remaja adalah aspek keluarga dan teman pergaulan di sekolah. ${ }^{13}$ Teman seusia yang dianggap hebat dapat mempunyai pengaruh yang sangat kuat terhadap mereka. Menanggapi hal tersebut, perangkat Desa Ngablak membentuk karang taruna sebagai ujung tombak kegiatan dalam rangka mewadahi generasi muda untuk melakukan kegiatan positif. Namun, selama beberapa penyelenggaraan kegiatan desa, masih ada beberapa anggota yang melakukan pesta minuman keras sehingga rawan terjadi penyalahgunaan alkohol.

Dalam rangka pembinaan generasi muda agar terhindar dari alkohol dan dampak negatifnya, perlu dilakukan upaya penanggulangan melalui pengembangan alternatif kegiatan positif di antaranya melalui pengenalan dan pengembangan potensi olahraga. Pada beberapa studi, diketahui bahwa konsumsi alkohol dapat menyumbang asupan energi berlebihan dan berkaitan dengan peningkatan berat badan dan massa lemak. ${ }^{14}$ Somatotipe, terutama endomorphy, pada remaja ditentukan oleh komposisi tubuh. ${ }^{15}$ Penelitian ini dilakukan untuk mengetahui karakteristik performance dan menentukan ada atau tidaknya perbedaannya antara generasi muda pengguna alkohol dengan yang tidak di Desa Ngablak, Kecamatan Ngablak, Kabupaten Magelang.

\section{Metode}

Penelitian ini menggunakan metode observasional dengan subjek generasi muda yang tergabung dalam karang taruna di Desa Ngablak sejumlah 50 orang. Pengambilan data dilakukan pada tanggal
23 Juli 2017 di Desa Ngablak, Kecamatan Ngablak, Kabupaten Magelang, Jawa Tengah.

Identifikasi penyalahgunaan alkohol dan NAPZA diperoleh melalui wawancara menggunakan kuesioner. Pemeriksaan fisik yang dilakukan meliputi denyut nadi, laju respirasi, tekanan darah, dan suhu badan. Tekanan darah dan suhu badan diukur menggunakan sphygmomanometer raksa $\left(\mathrm{ABN}^{\mathrm{TM}}\right)$ dan thermometer raksa $\left(\mathrm{OneMed}^{\circ}\right.$ ) berturut-turut. Pengambilan data riwayat penyakit dilakukan dengan metode wawancara.

Pengukuran untuk somatotipe dilakukan menggunakan pita ukur dan kaliper lipatan kulit (skinfold) pada sepuluh parameter pengukuran yaitu tinggi dan berat badan, lingkar lengan atas dan betis, tebal lipatan kulit trisep, subskapula, suprailiaka dan betis, serta lebar humerus dan femur. Pengukuran dilakukan sebanyak dua kali lalu hasil diratarata. Hasil tersebut kemudian digunakan untuk menghitung komponen somatotipe berdasarkan metode Heath Carter $^{16}$ sebagai berikut: $\mathrm{K} 1=-0,7182$ $+0,1451(X)-0,00068\left(X^{2}\right)+0,0000014\left(X^{3}\right)$ dengan $X$ = (penjumlahan trisep, subskapula, dan supraspinal skinfolds $(\mathrm{mm})) \times 170,18 /$ tinggi badan $(\mathrm{cm}) ; \mathrm{K} 2=$ $[0,858 \times$ lebar humerus $(\mathrm{cm})+0,601 \times$ lebar femur $+0,188 \times$ (lingkar lengan atas $(\mathrm{cm})-$ tebal lipatan kulit trisep $(\mathrm{mm}) / 10)+0,161 \times$ (lingkar betis $(\mathrm{cm})$ - tebal lipatan kulit betis $(\mathrm{mm}) / 10)-0,131 \times$ tinggi badan $(\mathrm{cm})+4,5]$; dan $\mathrm{K} 3=0,732 \times$ height weight ratio (HWR) apabila HWR $>40,74$; atau $0,463 \times$ HWR - 17,63 apabila 38,25 < HWR $\leq 40,74$; atau 0,1 apabila HWR $\leq 38,25$. HWR (height weight ratio) didapatkan dengan membagi tinggi badan dengan akar tiga dari berat badan. Tipe tubuh didapatkan berdasarkan plotting di bagan somatotipe. ${ }^{16}$

Analisis data dilakukan secara deskriptif, perbedaan karakteristik antropometri antara penyalahguna alkohol dan NAPZA dengan yang bukan dianalisis menggunakan independent t-test untuk uji parametrik dan uji Mann Whitney $U$ untuk uji non-parametrik. Interval kepercayaan yang digunakan adalah $95 \%$ sehingga nilai $p<0,05$ dinyatakan bermakna secara statistik. 


\section{Hasil}

Tabel 1 menunjukkan karakteristik responden termasuk data penyalahguna alkohol/ NAPAZA berdasar jenis kelamin. Subjek berjumlah 50 anak, 25 laki-laki (50,0\%) dan 25 perempuan (50,0\%), berusia 9 - 19 tahun, dan mayoritas merupakan siswa SMA/SMK (38,0\%).

Kondisi fisik subjek secara umum, frekuensi denyut nadi, frekuensi nafas, tekanan darah, dan suhu, dalam keadaan normal. Karakteristik riwayat penyakit subjek berdasarkan frekuensi meliputi asma/ alergi sebanyak 7 orang (14,0\%), riwayat pilek 4 orang $(8,0 \%)$, riwayat tifus 7 orang $(14,0 \%)$, serta riwayat mondok saat kecil, gangguan imun, penyakit mag, dan kejang masing-masing 1 orang $(2,0 \%)$.

Tabel 2 dan Tabel 3 menunjukkan karakteristik performance berdasarkan jenis kelamin dan kelompok penyalahguna pada subjek laki-laki dan perempuan berturut-turut. Terdapat 10 dari 25 orang $(40,0 \%)$ remaja laki-laki yang mengonsumsi alkohol. Rata-rata usia, tinggi badan, dan berat badan subjek laki-laki yang mengonsumsi alkohol lebih tinggi daripada yang tidak $(p<0,05)$. Hasil identifikasi menunjukkan bahwa kelompok remaja perempuan yang mengonsumsi alkohol hanya terdiri dari 2 orang sehingga tidak dapat dilakukan analisis statistik antarkelompok karena ketimpangan besar sampel. Tidak dijumpai remaja penyalahguna narkotika, psikotropika, dan zat aditif lainnya

Berdasarkan pengukuran antropometri dan perhitungan somatotipe didapatkan bahwa terdapat 2 bentuk tipe badan pada generasi muda Desa Ngablak, yaitu tipe ideal bagi remaja lakilaki dan tipe endo-mesomorfik pada perempuan. Tidak terdapat perbedaan somatotipe antara

Tabel 1. Karakteristik subjek

\begin{tabular}{|c|c|c|c|}
\hline & $\begin{array}{l}\text { Laki-laki } \\
(n=50)\end{array}$ & $\begin{array}{l}\text { Perempuan } \\
(\mathrm{n}=25)\end{array}$ & $\begin{array}{c}\text { Total } \\
(n=25)\end{array}$ \\
\hline Usia (tahun), rerata \pm SD & $15,0 \pm 2,5$ & $14,5 \pm 4,2$ & $14,8 \pm 2,3$ \\
\hline \multicolumn{4}{|l|}{ Pendidikan } \\
\hline SD, n (\%) & $3(12,0)$ & $3(12,0)$ & $6(12,0)$ \\
\hline SMP, n (\%) & $8(32,0)$ & $11(44,0)$ & $19(38,0)$ \\
\hline SMA/SMK, n (\%) & $13(52,0)$ & $10(40,0)$ & $23(46,0)$ \\
\hline Kuliah/lulus SMA/SMK, n (\%) & $1(4,0)$ & $1(4,0)$ & $2(4,0)$ \\
\hline Nadi (x/menit), rerata \pm SD & $82,4 \pm 11,3$ & $84,8 \pm 6,7$ & $83,6 \pm 9,3$ \\
\hline Laju respirasi $(x /$ menit), rerata $\pm S D$ & $19,2 \pm 2,5$ & $19,3 \pm 2,2$ & $19,2 \pm 2,3$ \\
\hline Tekanan darah sistole $(\mathrm{mmHg})$, rerata \pm SD & $119,2 \pm 7$ & $114,8 \pm 8,7$ & $117,0 \pm 8,1$ \\
\hline Tekanan darah diastole $(\mathrm{mmHg})$, rerata \pm SD & $74,8 \pm 8,2$ & $73,2 \pm 8,5$ & $74,0 \pm 8,3$ \\
\hline Suhu $\left({ }^{\circ} \mathrm{C}\right)$, rerata $\pm \mathrm{SD}$ & $36,3 \pm 0,1$ & $36,3 \pm 0,2$ & $36,3 \pm 0,2$ \\
\hline Tinggi badan $(\mathrm{cm})$, rerata \pm SD & $156,8 \pm 11,4$ & $150,2 \pm 5,9$ & $150,6 \pm 21,6$ \\
\hline Berat badan $(\mathrm{kg})$, rerata \pm SD & $50,0 \pm 13,4$ & $48,5 \pm 13,9$ & $48,7 \pm 13,5$ \\
\hline \multicolumn{4}{|l|}{ Penyalahguna alkohol/ NAPZA } \\
\hline Ya, n (\%) & $10(40,0)$ & $2(8,0)$ & $12(24,0)$ \\
\hline Tidak, n (\%) & $15(60,0)$ & $23(92,0)$ & $38(76,0)$ \\
\hline
\end{tabular}

SD: standar deviasi. 
Tabel 2. Karakteristik antropometri dan somatotipe remaja laki-laki di Desa Ngablak

\begin{tabular}{lccc}
\hline & $\begin{array}{c}\text { Penyalahguna alkohol } \\
\mathbf{n}=\mathbf{1 0}\end{array}$ & $\begin{array}{c}\text { Bukan penyalaguna } \\
\text { alkohol } \\
\mathbf{n}=\mathbf{1 5}\end{array}$ & $\boldsymbol{p}$ \\
\hline Usia (tahun) & $16,6 \pm 1,3$ & $14,0 \pm 2,5$ & $0,003^{1}$ \\
Tinggi badan (cm) & $164,1 \pm 4,9$ & $152,0 \pm 12,1$ & $0,002^{2}$ \\
Berat badan (kg) & $54,9 \pm 14,1$ & $45,0 \pm 11,8$ & $0,021^{2}$ \\
Lingkar lengan atas (cm) & $27,2 \pm 3,5$ & $25,0 \pm 3,2$ & $0,117^{1}$ \\
Lingkar betis (cm) & $33,2 \pm 3,3$ & $31,5 \pm 3,6$ & $0,249^{1}$ \\
Tebal lipatan kulit trisep (mm) & $8,6 \pm 3,1$ & $10,7 \pm 5,5$ & $0,579^{2}$ \\
Tebal lipatan kulit subskapula (mm) & $10,9 \pm 7,8$ & $12,3 \pm 8,5$ & $0,542^{2}$ \\
Tebal lipatan kulit suprailiaka (mm) & $11,9 \pm 11,7$ & $11,8 \pm 7,6$ & $0,657^{2}$ \\
Tebal lipatan kulit betis (mm) & $11,9 \pm 7,0$ & $11,1 \pm 4,8$ & $0,803^{2}$ \\
Lebar humerus (cm) & $6,2 \pm 0,4$ & $5,9 \pm 0,5$ & $0,151^{1}$ \\
Lebar femur (cm) & $9,1 \pm 0,9$ & $8,7 \pm 0,5$ & $0,373^{2}$ \\
Komponen somatotipe & & & - \\
$\quad$ K1 & $3,3 \pm 1,9$ & $4,0 \pm 1,8$ & - \\
$\quad$ K2 & $3,7 \pm 1,4$ & $4,1 \pm 1,0$ & - \\
$\quad$ K3 & $3,5 \pm 1,5$ & $3,1 \pm 1,5$ & Ideal \\
\hline Tipe tubuh & Ideal & & \\
\hline
\end{tabular}

Data disajikan dalam rerata \pm standar deviasi; nilai $p<0,05$ dinyatakan signifikan secara statistik. ${ }^{1}$ Berdasarkan uji $\mathrm{t}$, ${ }^{2}$ Berdasarkan uji Mann Whitney U.

Tabel 3. Karakteristik antropometri dan somatotipe remaja laki-laki di Desa Ngablak

\begin{tabular}{lcc}
\hline & $\begin{array}{c}\text { Penyalahguna alkohol } \\
(\mathbf{n}=\mathbf{2})\end{array}$ & $\begin{array}{c}\text { Bukan penyalahguna alkohol } \\
\text { (n = 23) }\end{array}$ \\
\hline Usia (tahun) & $16,6 \pm 1,3$ & $14,0 \pm 2,5$ \\
Tinggi badan (cm) & $164,1 \pm 4,9$ & $152,0 \pm 12,1$ \\
Berat badan (kg) & $54,9 \pm 14,1$ & $45,0 \pm 11,8$ \\
Lingkar lengan atas (cm) & $27,2 \pm 3,5$ & $25,0 \pm 3,2$ \\
Lingkar betis (cm) & $33,2 \pm 3,3$ & $31,5 \pm 3,6$ \\
Tebal lipatan kulit trisep (mm) & $8,6 \pm 3,1$ & $10,7 \pm 5,5$ \\
Tebal lipatan kulit subskapula (mm) & $10,9 \pm 7,8$ & $12,3 \pm 8,5$ \\
Tebal lipatan kulit suprailiaka (mm) & $11,9 \pm 11,7$ & $11,8 \pm 7,6$ \\
Tebal lipatan kulit betis (mm) & $11,9 \pm 7,0$ & $11,1 \pm 4,8$ \\
Lebar humerus (cm) & $6,2 \pm 0,4$ & $5,9 \pm 0,5$ \\
Lebar femur (cm) & $9,1 \pm 0,9$ & $8,7 \pm 0,5$ \\
Komponen somatotipe & & \\
$\quad$ K1 & $3,3 \pm 1,9$ & $4,0 \pm 1,8$ \\
$\quad$ K2 & $3,7 \pm 1,4$ & $4,1 \pm 1,0$ \\
$\quad$ K3 & $3,5 \pm 1,5$ & $3,1 \pm 1,5$ \\
Tipe tubuh & Ideal & Ideal \\
\hline
\end{tabular}

Data disajikan dalam rerata \pm standar deviasi 


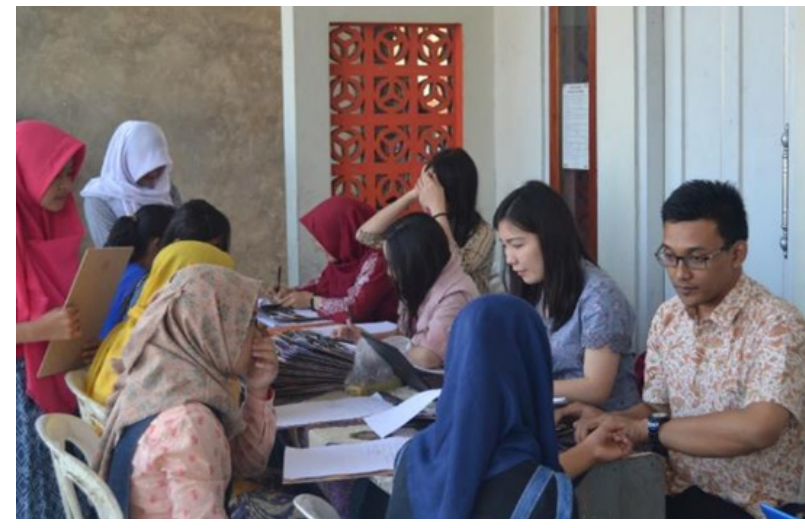

(a)



(b)

Gambar 1. Pemeriksaan fisik (a) dan penimbangan berat badan dan tinggi badan (b)

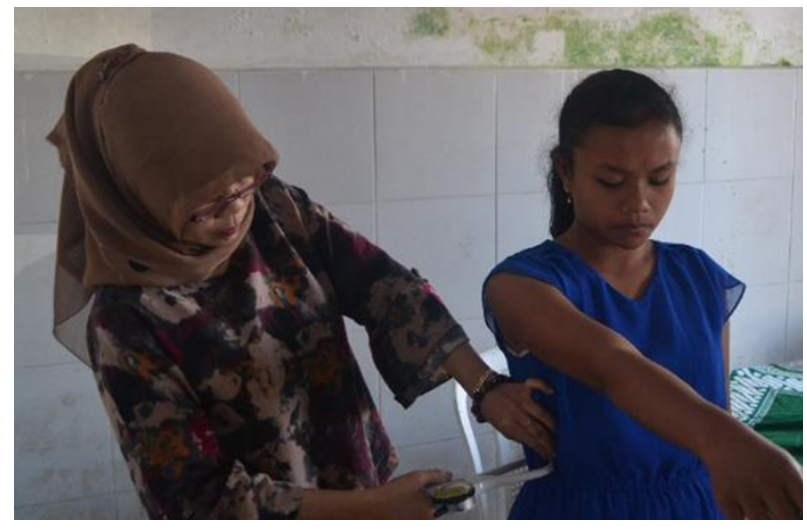

(a)

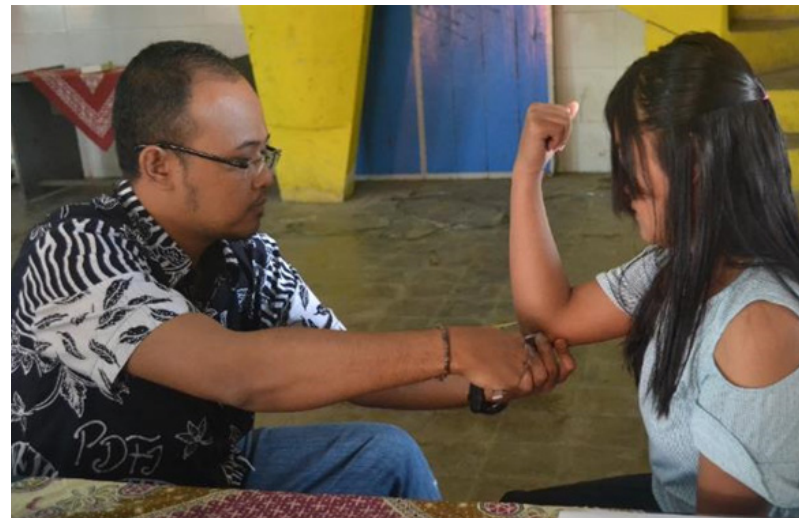

(b)

Gambar 2. Pengukuran ketebalan lemak (a) dan pengukuran lebar humerus (b)

penyalahguna alkohol dan yang bukan, baik pada laki-laki maupun perempuan. Gambar 1 dan Gambar 2 menunjukkan proses pengambilan data.

\section{Pembahasan}

Generasi muda Desa Ngablak berpotensi untuk berkembang optimal karena bermukim di sebuah desa yang terletak $13 \mathrm{~km}$ dari puncak Gunung Merapi, di mana sumber alamnya indah untuk objek wisata, daerahnya sejuk, tanaman buah dan sayurnya tumbuh subur, dan memungkinkan untuk wisata agro serta pengembangan ekonomi daerah. ${ }^{17,18}$ Potensi budaya yang dimiliki mencakup kesenian campur sari, lagu-lagu tembang jawa, serta kesenian kubro siswo. Pentas kesenian biasa dilakukan pada pukul sembilan malam hingga lima pagi dan memiliki babak saat pemain kerasukan setan. Kondisi masyarakat Desa Ngablak yang mayoritas memiliki tingkat pendidikan rendah (sebagian besar SD), ${ }^{12}$ mudah mendapatkan uang dari hasil pertanian, dan rentan terhadap pengaruh budaya kesenian maupun mitos menyebabkan warganya rentan terhadap penyalahgunaan alkohol dan terjadinya tindak kejahatan. ${ }^{9,19}$

Sebagian besar subjek penelitian adalah pelajar SMA/SMK yaitu sebanyak 24 orang $(48,0 \%)$ dan pelajar di bangku SMP sebanyak 19 orang $(38,0 \%)$. Usia subjek berkisar antara 8 - 19 tahun dengan usia rata-rata subjek laki-laki yang mengonsumsi alkohol adalah 16,6 tahun, sedangkan yang tidak adalah 14 tahun $(p<0,01)$. Hasil ini sesuai dengan penelitian Pratama (2013), di salah satu desa di Jawa Timur di mana mayoritas generasi muda yang mengonsumsi alkohol di daerah tersebut berusia 19 - 24 tahun $(65,1 \%)$ dan $16-18$ tahun $(34,9 \%)$, serta tidak ada yang berusia $11-15$ tahun. $^{20}$ 
Menurut hasil analisis Survei Kesehatan Remaja Indonesia (SKRI), jenis kelamin merupakan determinan paling dominan dari perilaku berisiko pada remaja. Berdasarkan data tersebut, lakilaki generasi muda berusia 15 - 24 tahun 10 kali lebih berpotensi untuk mengonsumsi alkohol dibandingkan perempuan dengan rentang usia yang sama. ${ }^{21}$ Pada penelitian ini, sebanyak 10 orang subjek laki-laki (20,0\%) mengonsumsi alkohol, sedangkan hanya 2 orang remaja perempuan $(4,0 \%)$ yang melakukan hal serupa. Hal ini menunjukkan bahwa jumlah subjek remaja lakilaki yang mengonsumsi alkohol 5 kali lipat jumlah subjek perempuan.

Pemeriksaan somatotipe merupakan salah satu teknik untuk menggambarkan tipe dan komposisi tubuh seseorang. ${ }^{15}$ Teknik ini didasarkan pada perkembangan jaringan embrional yang dilakukan dengan mengukur segmen-segmen badan. ${ }^{16}$ Hasil pengukuran terhadap para remaja di Desa Ngablak menunjukkan bahwa terdapat dua bentuk tipe badan pada remaja-remaja tersebut. Dilihat dari rerata somatotipenya, sebagian besar remaja lakilaki baik yang meminum alkohol maupun yang tidak, memiliki tipe tubuh ideal, sedangkan pada remaja perempuan, sebagian besar mempunyai somatotipe endo-mesomorfik atau bertipe sedang cenderung gemuk. Hal ini sejalan dengan studi populasi pada generasi muda suku Jawa di Kabupaten Magelang yang menunjukkan bahwa total persen lemak subjek perempuan meningkat seiring bertambahnya usia dengan rata-rata persen lemak tubuh sekitar $22,0 \%$ pada usia 15 tahun dan mencapai di atas $25,0 \%$ pada usia 19 tahun. Pada usia 17 tahun, subjek perempuan memiliki massa lemak dua kali lipat dari laki-laki. ${ }^{22}$ Tipe-tipe somatotipe pada penelitian ini normal bagi remaja dengan usia 14 - 16 tahun karena pada masa tersebut remaja sedang pada masa pubertas.

Penelitian oleh Kim (2012) pada populasi di Korea menunjukkan bahwa konsumsi alkohol berhubungan dengan penurunan massa lemak subkutan dan peningkatan lemak viseral. ${ }^{23}$ Meski demikian, suatu metaanalisis menyebutkan bahwa kemungkinan konsumsi alkohol dalam memengaruhi komposisi tubuh sangat bergantung pada faktor lainnya, termasuk jenis kelamin, frekuensi dan jumlah alkohol, aktivitas fisik, serta pola dan perilaku makan. ${ }^{14}$ Pada penelitian ini, kecenderungan konsumsi alkohol pada kelompok remaja laki-laki tidak menyebabkan terjadinya perbedaan tipe badan dengan remaja yang bukan pecandu alkohol. Hal ini kemungkinan terjadi karena jumlah subjek yang relatif sedikit. Selain itu, hal ini dapat disebabkan oleh remaja pecandu alkohol yang tetap melakukan aktivitas fisik dengan konsumsi makan yang normal seperti remaja bukan pecandu sehingga tidak ada perbedaan di antara kedua kelompok tersebut.

Tipe badan ideal yang terdapat pada kelompok laki-laki remaja Desa Ngablak jika dihubungkan dengan jenis olahraga yang sesuai adalah olahraga yang membutuhkan aktivitas fisik yang banyak, seperti basket, softball, sepak bola, atau olahraga yang memerlukan kontak fisik. ${ }^{16,24,25}$ Tipe endomesomorfik pada kelompok perempuan biasanya banyak ditemui pada atlet basket, softball, futsal, bola voli, dan cabang olahraga dengan kontak fisik. ${ }^{16,26}$ Hasil pemeriksaan antropometri, fisik, dan identifikasi penyalahguna NAPZA merupakan upaya awal kegiatan pencegahan penyalahangunaan alkohol di Desa Ngablak yang selanjutnya dapat digunakan dalam upaya pengembangan potensi/ bakat individu dalam jenis olahraga yang sesuai dengan performance yang dimiliki.

\section{Kesimpulan}

Kecenderungan penyalahgunaan alkohol tidak menyebabkan terjadinya perbedaan tipe badan pada remaja, baik pada laki-laki maupun perempuan. Pada generasi muda Desa Ngablak didapatkan tipe tubuh ideal pada remaja laki-laki dan tipe endo-mesomorfik pada perempuan.

Kami menyarankan agar penelitian dan pengabdian kepada masyarakat ini diperluas ke daerah desa binaan lain dari Fakultas Kedokteran, Kesehatan Masyarakat, dan Keperawatan (FKKMK) Universitas Gadjah Mada (UGM) di wilayah Daerah Istimewa Yogyakarta dan Jawa Tengah untuk menghindarkan generasi muda dari bahaya alkohol dan NAPZA dalam cakupan yang 
lebih luas. Pemerintah daerah diharapkan dapat mendukung dan memfasilitasi generasi muda untuk mengembangkan bakat yang dimiliki sesuai karakteristik performance mereka serta memonitor upaya pencegahan penyalahgunaan alkohol dan NAPZA di masyarakat.

\section{Ucapan terima kasih}

Terima kasih kami ucapkan kepada FK-KMK UGM, yang telah memberikan dana sehingga kegiatan kegiatan pengabdian kepada masyarakat ini dapat berlangsung, serta kepada Camat Kecamatan Ngablak, Kepala Desa Ngablak, beserta jajarannya yang telah memberi izin, sarana dan prasarana, mulai dari persiapan tempat, penyebaran undangan untuk peserta, dan sampai pelaksanaan kegiatan. Tidak ada konflik kepentingan dalam penelitian dan pengabdian kepada masyarakat ini.

\section{Daftar pustaka}

1. World Health Organization. Global status report on alcohol and health 2018. Geneva: World Health Organization; 2018.

2. Kementerian Kesehatan Republik Indonesia. Riset kesehatan dasar 2007. Jakarta: Badan Penelitian dan Pengembangan Kesehatan, Departemen Kesehatan, Republik Indonesia; 2008.

3. Kopun M, Propping P. The kinetics of ethanol absorption and elimination in twins and supplementary repetitive experiments in singleton subjects. Eur J Clin Pharmacol. 1977;11(5):337-44.

4. Suhartini, Mustofa, Nurhantari Y, Rianto BUD. The analysis of polymorphism of alcohol dehydrogenase 3 (adh3) gene and influence of liver function status in indonesia. Kobe $J$ Med Sci. 2017;62(4):107-13.

5. Louvet A, Mathurin P. Alcoholic liver disease: Mechanisms of injury and targeted treatment. Nat Rev Gastroenterol Hepatol. 2015;12(4):231-42.

6. Lean MEJ, Vlachou P, Govan L, Han TS. Different associations between body composition and alcohol when assessed by exposure frequency or by quantitative estimates of consumption. $J$ Hum Nutr Diet. 2018;31(6):747-57.

7. Jayne $M$, Valentine $G$. Alcohol-related violence and disorder. Prog Hum Geogr. 2016;40(1):6787.

8. Steele CM, Southwick L. Alcohol and social behavior: I. The psychology of drunken excess. J Pers Soc Psychol. 1985;48(1):18-34.

9. Rohma A. 25 efek bahaya alkohol bagi kesehatan dan kehidupan sosial [Internet]. HaloSehat Health Media Group; 2015 [cited 2018 November 2]. Available from: https:// halosehat.com/farmasi/aditif/25-efek-bahayaalkohol-bagi-kesehatan-dan-kehidupan-sosial

10. Badan Pusat Statistik Kabupaten Magelang. Luas daerah, jarak terdekat/termudah dari ibukota kabupaten ke kecamatan di Kabupaten Magelang dan ketingggian dari permukaan laut 2015 [Internet]. Badan Pusat Statistik Kabupaten Malang; 2015 [cited 2018 November 2]. Available from: https://magelangkab. bps.go.id/statictable/2015/09/10/73/ luas-daerah-jarak-terdekat-termudahdari-ibukota-kabupaten-ke-kecamatan-dikabupaten-magelang-dan-ketingggian-daripermukaan-laut-2015.html

11. Sistem Informasi Desa Ngablak. Grafik data demografi berdasar pekerjaan [Internet]. [updated 2018, cited 2018 November 2]. Available from: http://desangablak. magelangkab.go.id/index.php/first/statistik/1

12. Badan Pusat Statistik Kabupaten Magelang. Persentase penduduk 15 tahun ke atas yang bekerja selama seminggu yang lalu menurut tingkat pendidikan yang ditamatkan dan jenis kelamin 2015 [Internet]. Badan Pusat Statistik Kabupaten Magelang; 2015 [cited 2018 November 2]. Available from: https://magelangkab.bps.go.id/ statictable/2016/11/02/220/persentasependuduk-15-tahun-ke-atas-yang-bekerjaselama-seminggu-yang-lalu-menurut-tingkatpendidikan-yang-ditamatkan-dan-jeniskelamin-2015.html

13. Kusuma YLH. Faktor lingkungan yang melatar 
belakangi konsumsi minum-minuman keras pada remaja di Desa Gayaman Kecamatan Mojoanyar - Mojokerto. Jurnal Ilmiah Kesehatan Politeknik Kesehatan Majapahit. 2016;8(2):113-22.

14. Traversy G, Chaput J-P. Alcohol consumption and obesity: An update. Curr Obes Rep. 82015;4(1):122-30.

15. Lizana PA, González S, Lera L, Leyton B. Association between body composition, somatotype and socioeconomic status in chilean children and adolescents at different school levels. J Biosoc Sci. 2018;50(01):53-69.

16. Carter L, Heath B. Somatotyping: Development and applications. Cambridge: Cambridge University Press; 1990.

17. Komarawidjaja W. Dampak budidaya pertanian intensif terhadap kualitas air permukaan Desa Kanigoro Kecamatan Ngablak Kabupaten Magelang. Jurnal Teknologi Lingkungan. 2016;12(1):75-84.

18. Saputra MR, Rodhiyah R. Strategi pengembangan wisata di kawasan Gunung Andong Magelang. J Ilmu Adm Bisnis S1 Undip. 2016;5(4):571-86.

19. Parlesak A, Billinger MH-U, Bode C, Bode JC. Gastric alcohol dehydrogenase activity in man: influence of gender, age, alcohol consumption and smoking in a caucasian population. Alcohol Alcohol. 2002;37(4):388-93.

20. Pratama VND. Perilaku remaja pengguna minuman keras di Desa Jatigono Kecamatan Kunir Kabupaten Lumajang. Jurnal Promkes.
$2013 ; 1(2)$.

21. Lestary $H$, Sugiharti S. Perilaku berisiko remaja di indonesia menurut Survey Kesehatan Reproduksi Remaja Indonesia (SKRRI) tahun 2007. Jurnal Kesehatan Reproduksi. 2011;1(3).

22. Widiyani T, Suryobroto B, Budiarti S, Hartana A. The growth of body size and somatotype of javanese children age 4 to 20 years. HAYATI J Biosci. 2011;18(4):182-92.

23. Kim KH, Oh S-W, Kwon H, Park J-H, Choi $\mathrm{H}$, Cho B. Alcohol consumption and its relation to visceral and subcutaneous adipose tissues in healthy male Koreans. Ann Nutr Metab. 2012;60(1):52-61.

24. Giannopoulos N, Vagenas G, Noutsos K, Barzouka K, Bergeles N. Somatotype, level of competition, and performance in attack in elite male volleyball. J Hum Kinet. 2017;58:131-40.

25. Cárdenas-Fernández V, Chinchilla-Minguet JL, Castillo-Rodríguez A. Somatotype and body composition in young soccer players according to the playing position and sport success. J Strength Cond Res. 2017;1.

26. Gholami M, Rad LS. Anthropometric, body composition and somatotype differences of Iranian elite female basketball and handball players. Br J Sports Med. 2010;44(14):19-20. 